Landslides (2019) 16:195-200 DOI 10.1007/s10346-018-1114-x Received: 2 November 2018 Accepted: 12 November 2018 Published online: 28 November 2018 (C) The Author(s) 2018
Shinji Sassa - Tomohiro Takagawa

\section{Liquefied gravity flow-induced tsunami: first evidence and comparison from the 2018 Indonesia Sulawesi earthquake and tsunami disasters}

\begin{abstract}
On 28 September 2018, a strong earthquake with a moment magnitude of 7.5 occurred on the island of Sulawesi, Indonesia. This earthquake caused extensive liquefaction and liquefaction-induced flow slides inland. Despite a strike-slip fault, which typically displaces land horizontally, being unlikely to produce significant tsunamis, the earthquake in fact caused devastating tsunamis. Our field investigations showed that there was an occurrence of extensive liquefaction in coastal areas. Significant coastal liquefaction can result in a gravity flow of liquefied soil mass that can cause a tsunami. A comparison with a past disaster of the strike-slip fault Haiti earthquake tsunami indicated that essentially the same occurred at the Palu coast of Central Sulawesi. Namely, liquefaction-induced total collapse of coastal land caused liquefied sediment flows, resulting in a tsunami. An important difference between this time and Haiti was that such total collapses and flows of coastal land due to liquefaction occurred at several (at least nine) places, resulting in multiple tsunamis. Analysis of the tidal data implied that less than $20 \%$ of the tsunami height was related to tectonic processes, and the majority was caused by the coastal and submarine landslides as characterized by liquefied gravity flows.
\end{abstract}

Keywords Coastal and submarine landslide · Liquefaction · Gravity flow $\cdot$ Tsunami $\cdot$ Sulawesi earthquake

\section{Introduction}

The 2018 Indonesia Sulawesi earthquake and tsunami disasters that took place on 28 September caused more than 2000 fatalities. The focal mechanism of the earthquake was strike-slip faulting. From the distribution of aftershocks, it is estimated that the fault length was over $150 \mathrm{~km}$. Comparing satellite images before and after the earthquake, it is revealed that the fault traversed $20 \mathrm{~km}$ across the Pal Bay in the North-South direction, and the east and west sides of the fault moved about $4 \mathrm{~m}$ past each other to the north and the south, respectively (Valkaniotis 2018). Due to the strong ground shaking, extensive liquefaction and liquefaction-induced flow slides with several hundred meters to kilometer scale flow-out distances were observed inland (Fig. 1). Field investigations were conducted inland and along coastal land on 17 to 19 October 2018. The basic mechanism at work in the liquefaction and liquefied flows in Palu city, Central Sulawesi may be described as follows. First, alluvial thick loose deposits of sand with high groundwater level were subjected to a strong ground shaking of the $\mathrm{Mw}=7.5$ earthquake with its shallow focal depth of $<10 \mathrm{~km}$. Second, the ground contained a certain amount of silt and clay, with essential fractions being sand, and these may have enhanced the flowability of the liquefied soil. Third, the presence of confined groundwater imposed osmotic pressure, namely, seepage, on the occurrence of liquefaction and further promoted the flowability of the liquefied soil. All these factors may have helped the substantial liquefied flows occur on a very gentle inland slope of around only $1^{\circ}$ (Fig. 1).

Coastal inundation surveys showed that the tsunami inundation height was 3-4 $\mathrm{m}$ on average around the Palu bay and, was as high as $6.8 \mathrm{~m}$ in localized areas above the mean sea level and $6.2 \mathrm{~m}$ above the astronomical tide level when the earthquake occurred (the splash was excluded). These inundation heights are consistent with the prior observations made by the International Research Institute of Disaster Science (IRIDeS) at Tohoku University (2018). The average inundation distance was around $200 \mathrm{~m}$, which is very short. This implies that the spatial extent of the tsunami source was much smaller than the scale of tectonic deformation of the Mw 7.5 earthquake.

Below, we present and discuss the liquefaction and liquefactioninduced phenomena that occurred along the Palu coast of Central Sulawesi, Indonesia.

\section{Coastal liquefaction}

The field investigations along the Palu coast revealed a new evidence of the extensive liquefaction in these areas, not only inland but also at coastal land. The liquefied area confirmed and the corresponding representative remains/situations indicating the occurrence of liquefaction are shown in Fig. 2. The two photographs put side by side on the upper right show pipes that came up to the ground surface and lay randomly half-buried in the ground, showing that the ground was once liquefied. The photographs at the center right show the situations where liquefaction-induced sand boils accompanied fine silt and clay content that deposited on the soil surface and subsequently became dehydrated and remained as films containing voids and cracks. The corresponding side photograph shows remains of boils with fine content as confirmed just after the 2018 Hokkaido Eastern Iburi Earthquake in Japan, which occurred on September 2018. Both share the same characteristics mentioned above, showing the occurrence of liquefaction. The photograph on the lower right shows large remains of sand boils just behind a structure that prevented the ejecta from being washed away by the tsunami, thus showing a clear evidence of liquefaction. The photograph to the right also shows sand ejecta spreading over the original ground. All these features are clear evidence of the liquefaction occurrence. These small pieces of evidence are identified from neither aerial photographs nor satellite images. They can be obtained only through direct and close observations on site.

\section{Features of liquefied gravity flows}

A gravity flow of liquefied sediment is a phenomenon triggered by a significant coastal liquefaction, which is then followed by the collapse 

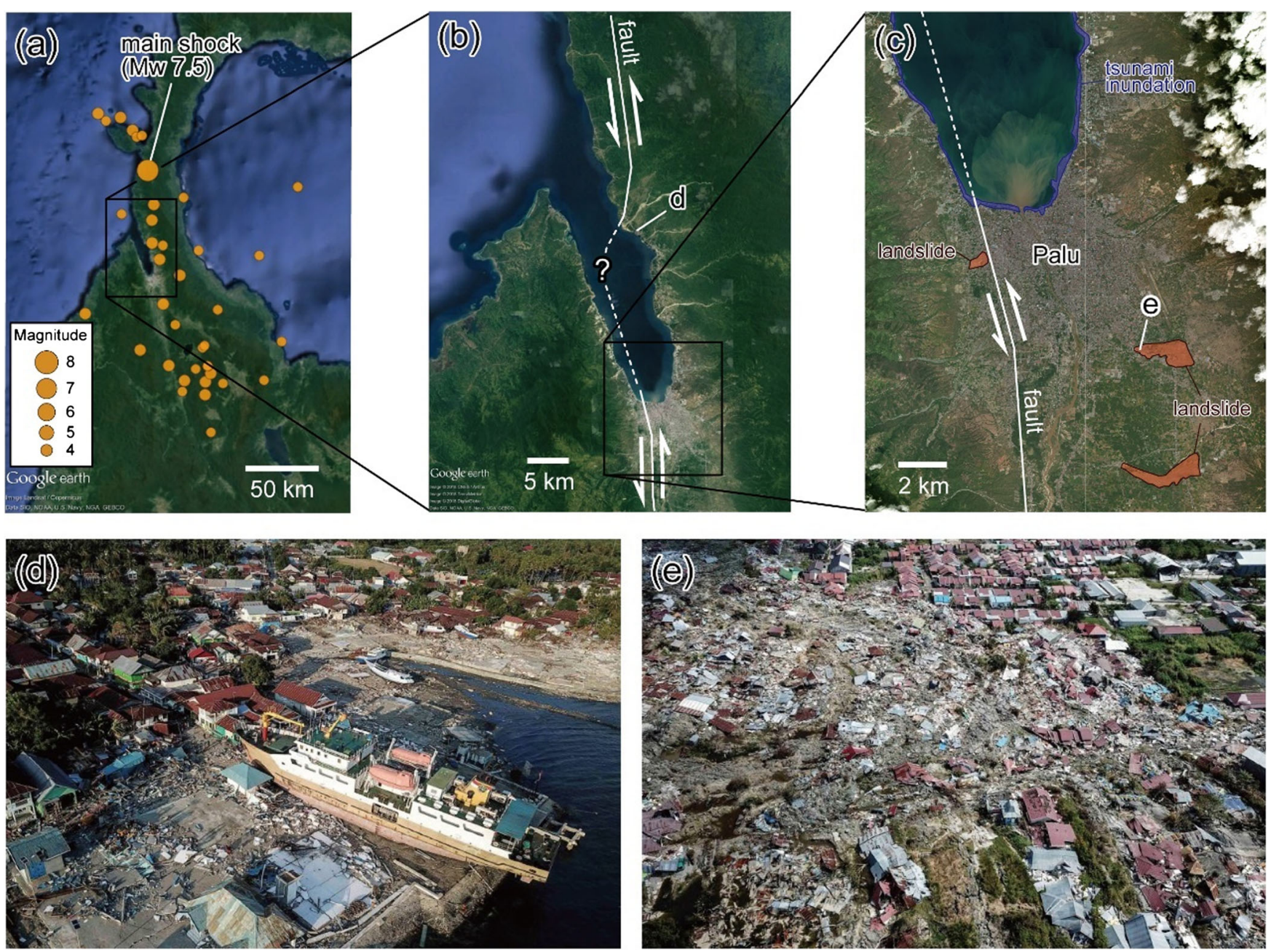

Fig. 1 a Spatial distribution of the epicenters of the Sulawesi earthquake and aftershocks within 3 days (USGS 2018). $\mathbf{b}$ The fault crosses the Palu Bay and Palu city in the North-South direction (Valkaniotis 2018). c The areas of tsunami inundation and landslides are marked (satellite image: Digital Globe Open data Program 2018). Destructive tsunamis struck the coastal area (d) and kilometer-scale landslides (e) occurred in several places (photos: Reuters (2018), both locations are shown in b and c, respectively)

of the liquefied soil under gravity. It is categorized as a coastal/ submarine landslide that transforms itself into a high-density gravity flow and subsequently flows out over a long distance, leading to redeposition. The concurrent processes and the dynamics of liquefied gravity flow that may have a significant impact on tsunami generation are governed by two-phase physics (Sassa and Sekiguchi 2010, 2012).

\section{Liquefied gravity flow-induced tsunami: comparison with the past disaster and analysis}

The 2010 Haiti earthquake, with a moment magnitude of 7.0, represented a strike-slip fault earthquake that was unlikely to produce significant tsunami, but nevertheless generated substantial tsunamis at coastal areas. In the Haiti case, an extensive liquefaction took place in the river delta area, and accordingly an area of coastal land extending for $400 \mathrm{~m}$ in the along-shore direction and $100 \mathrm{~m}$ in the cross-shore direction totally collapsed and flowed away, generating a substantial tsunami with the maximum flow depth of $3 \mathrm{~m}$ and a greater inundation height at the coast (Hornbach et al. 2010). The Haiti case shares three important characteristics with the present Sulawesi case: (1) both were strike-slip fault earthquakes, (2) substantial tsunamis, and (3) liquefactions occurred. Further, the Haiti coastal geography also shares the same basic features with the Palu bay, such as the average sea bottom slope of 1:5, namely, a 200-m water depth is reached at $1 \mathrm{~km}$ offshore distance (Badan Informasi Geospasial 2018a). For the purpose of comparison, the Haiti coast and the Palu coast before and just after the earthquake are shown side by side in Fig. 3 on the same spatial scale. The comparison, together with the results and evidence obtained from the field investigations conducted at the Palu coast, described above, indicate that essentially the same phenomena occurred at both coasts. Namely, the strong strike-slip fault earthquake caused liquefaction, triggering the total collapse of the coastal land and its flow that resulted in a substantial tsunami. 


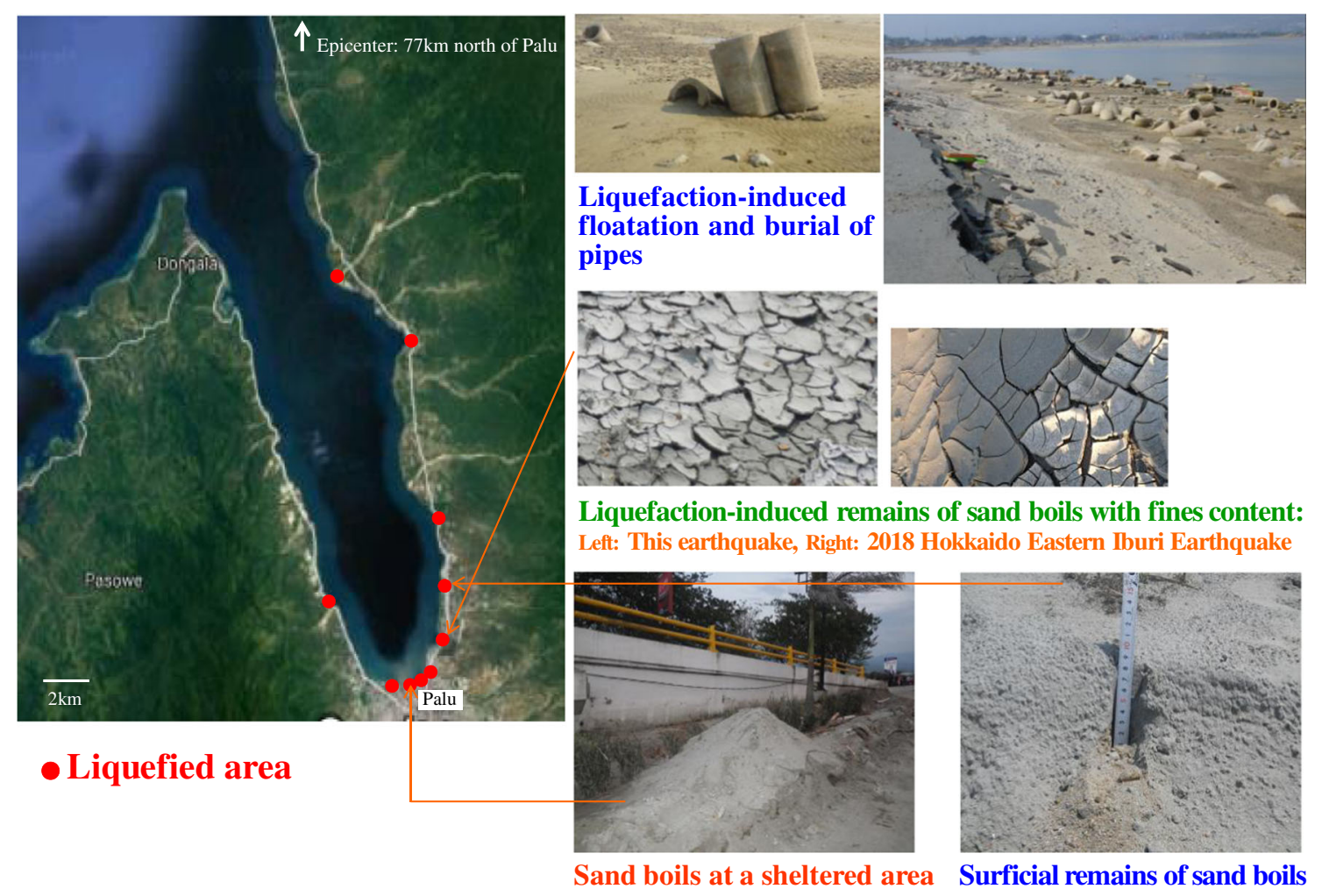

Fig. 2 Evidence of extensive coastal liquefaction along Palu coast

A notable difference between the 2010 Haiti earthquake and the 2018 Sulawesi earthquake is that such liquefaction-induced total collapse and the subsequent flow of coastal land occurred not only at one place, as in the Haiti earthquake, but at several (at least nine) places, simultaneously causing multiple substantial tsunamis throughout the bay and coastal areas, as shown in
Haiti Coast 2010
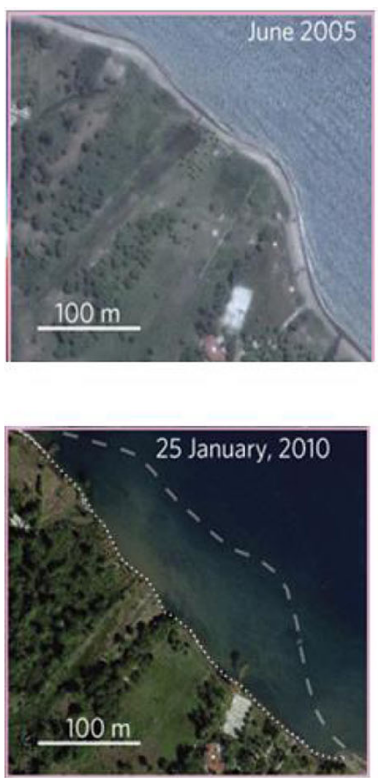

\section{Before earthquake: August 22 Palu Coast 2018}

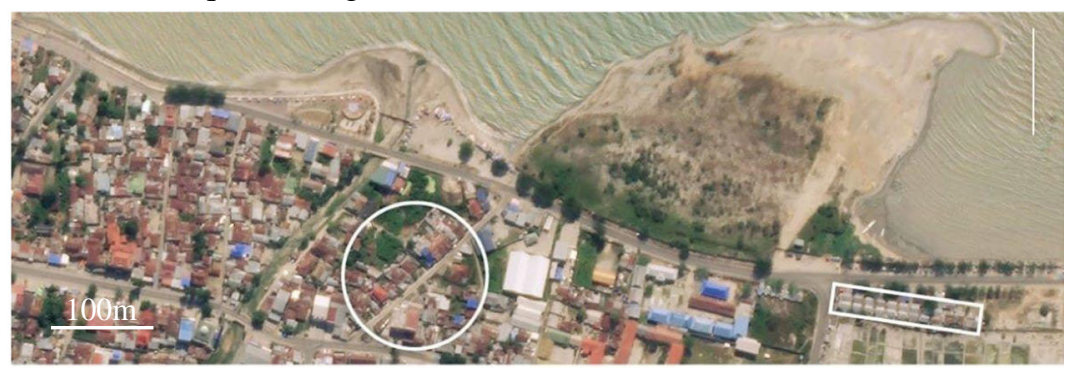

After earthquake: October 1

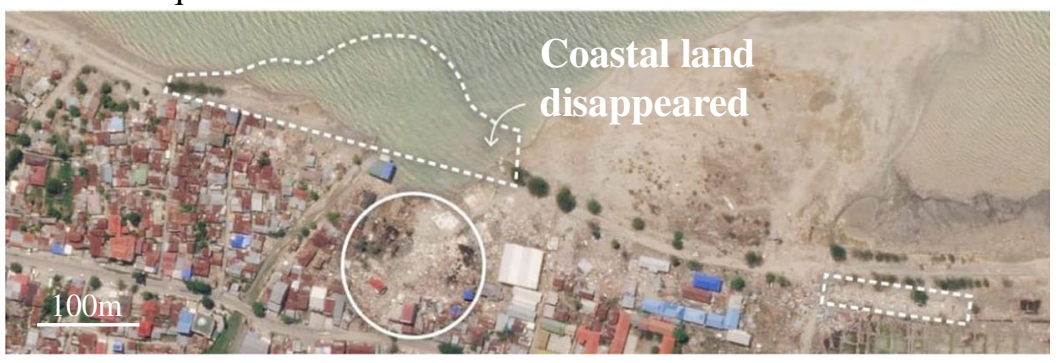

Fig. 3 Comparison of the Haiti coast (Hornbach et al. 2010) and the Palu coast (Reuters Graphics 2018) before and just after the Haiti and Sulawesi earthquakes. For the purpose of clarity, a white dotted line has been added at the land-sea interface on the image taken on 25 January 2010 of Hornbach et al. (2010) 

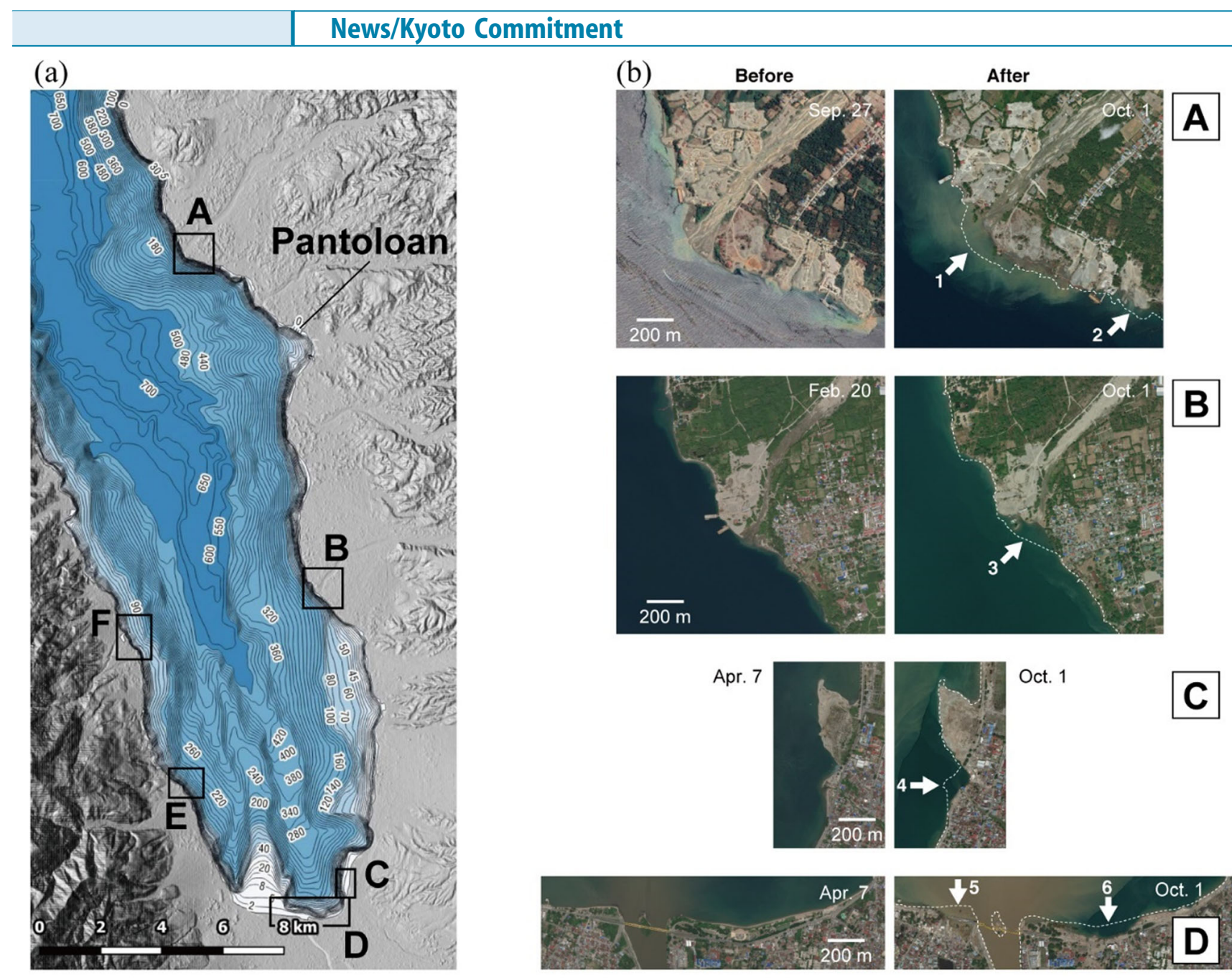

Apr. 7
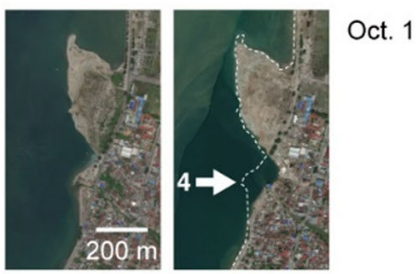

C
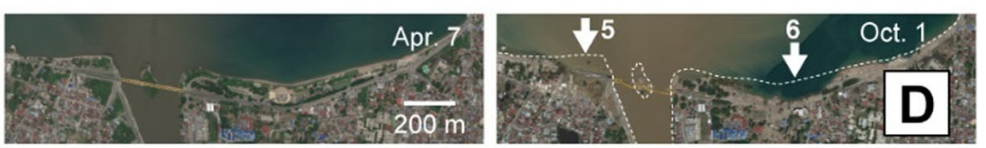

(c)
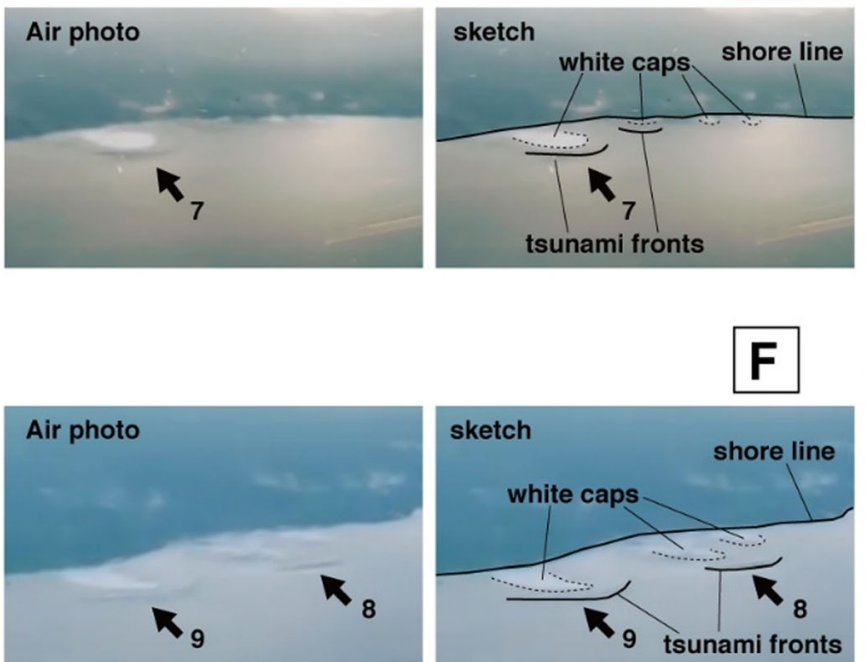
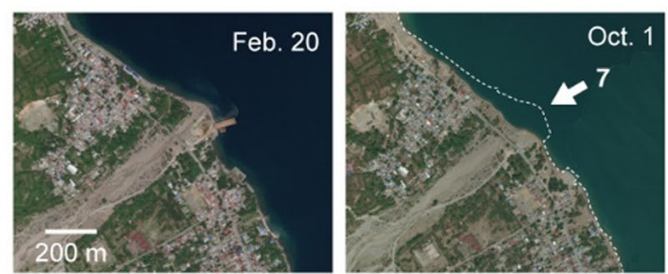

E
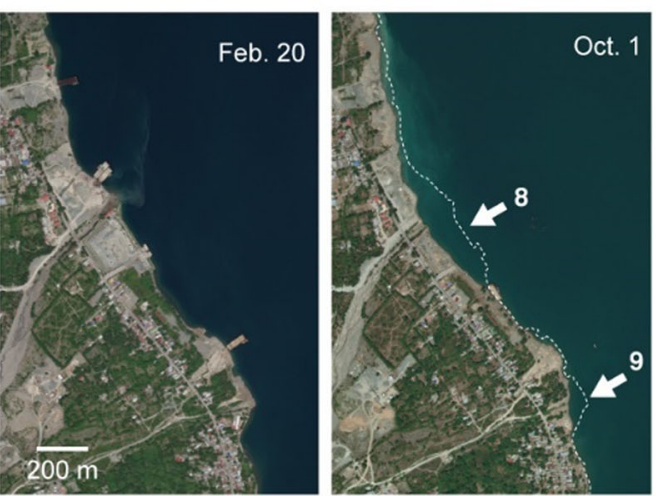

Fig. 4 a Bathymetry of Palu Bay (Badan Informasi Geospasial 2018a) and the locations of major coastal retreat (A-F). b Comparisons of satellite images before and after the earthquake (A, Sep. 27: CNES/Airbus 2018; A, Oct. 1 and B-F: Digital Globe Open data Program 2018). Significant coastal retreat areas are indicated by white arrows (No. 1-9). c Aerial photos of multiple tsunami occurrence at the areas E and F, taken just after the earthquake by Mafella (2018). Interpreted sketches are shown aside. The black arrows indicate tsunami fronts and the arrows with numbers 7-9 match those with the same numbers in the satellite images of areas $E$ and $F$ in $\mathbf{b}$. White caps of breaking waves are shown on the land side of the tsunami fronts 

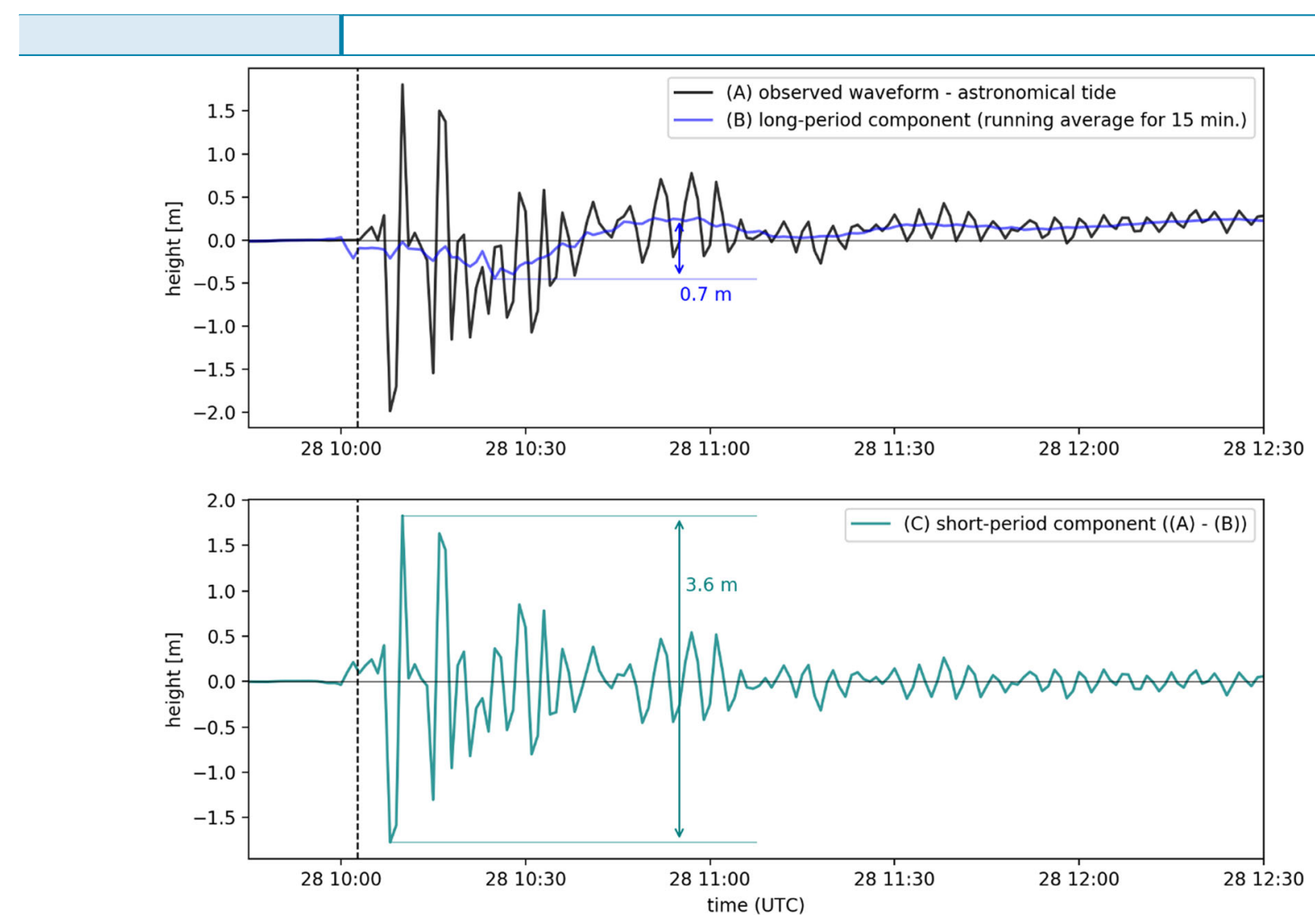

Fig. 5 Analysis of the tidal measurements at Pantoloan. The 1-min-interval data was used for analysis of tsunami signals which were obtained by digitizing a tide chart (Sudibyo 2018). For extracting the astronomical tide, a long-term tide record with 2-3 min interval (Badan Informasi Geospasial 2018b) was used

Fig. 4(a-c). From a comparison of satellite images (CNES/Airbus 2018; Digital Globe Open Data Program 2018) before and after the earthquake, substantial levels of coastal retreat were detected (Fig. 4(b)). Places where major coastal retreat occurred are indicated by white arrows. Additionally, direct observation of tsunami occurrence in areas $\mathrm{E}$ and $\mathrm{F}$ are shown in Fig. 4(c). These captured images were taken from an airplane just after the earthquake (Mafella 2018). Note that all of the locations 7,8 , and 9 of tsunami occurrence marked by black arrows in the images match the corresponding locations of major coastal retreat. Therefore, Fig. 4(b), (c) shows evidence of the occurrence of multiple tsunamis exactly at locations where the above phenomena took place.

Analysis of the tidal data at Pantoloan (see the location in Fig. 4(a)) shows that the long-period component with a period of about $1 \mathrm{~h}$ was $0.7 \mathrm{~m}$ in height, whereas the short-period component with a period of a few minutes was $3.6 \mathrm{~m}$ in height, as shown in Fig. 5. On the basis of the field evidence and comparison described above, the results imply that only $16 \%$ of the tsunami amplitude was attributable to large-scale tectonic processes, whereas the majority $(84 \%)$ of the tsunami amplitude was most likely due to the more concentrated coastal and submarine landslides as characterized by liquefied gravity flows.
Summary

A summary of the findings from the present field investigations and analysis of the 2018 Indonesia Sulawesi earthquake and tsunami disasters is as follows.

- Our field investigation revealed new evidence of extensive liquefaction in coastal areas, not only inland but also along the coast.

- Significant coastal liquefaction resulted in liquefied sediment flows, causing tsunami: liquefied gravity flow-induced tsunami.

- Integrated use of multiple field evidence, state-of-the-art knowledge of liquefied gravity flows, and comparison with a past disaster involving a strike-slip fault earthquake and tsunami, together with analysis of tidal data, showed that the liquefied gravity flows induced multiple tsunamis, and hence, most of the earthquake and tsunami disasters in the 2018 Sulawesi earthquake stemmed from liquefaction.

- Considering liquefaction risks and taking appropriate measures are thus crucial for mitigating the impacts of future earthquakes and tsunamis.

\section{Acknowledgements}

The field investigation was conducted by the authors as members of the mission team for damage and needs assessment of the Japan International Cooperation Agency (JICA) in cooperation with the 
Ministry of Land, Infrastructure, Transport and Tourism (MLIT), Japan. Both authors would like to thank JICA and MLIT for their assistance and cooperation during the field work.

Funding information This work was supported in part by JSPS KAKENHI Grant Numbers JP15Ho2265 and JP15Ho4052.

Open Access This article is distributed under the terms of the Creative Commons Attribution 4.0 International License (http:// creativecommons.org/licenses/by/4.0/), which permits unrestricted use, distribution, and reproduction in any medium, provided you give appropriate credit to the original author(s) and the source, provide a link to the Creative Commons license, and indicate if changes were made.

\section{References}

Badan Informasi Geospasial (2018a) Contour map of Palu Bay, Retrieved from https:// cloud.big.go.id. Accessed 30 Oct 2018

Badan Informasi Geospasial (2018b) Real time tidal observation, Retrieved from http:// tides.big.go.id:8888/dash/. Accessed 30 Oct 2018

CNES/Airbus (2018) Satellite image of Labua, Sulawesi, Indonesia. Retrieved from http:// www.earth.google.com. Accessed 30 Oct 2018

Digital Globe Open data Program (2018) Satellite images of Palu and Donggala, Sulawesi, Indonesia, Retrieved from https://www.digitalglobe.com/opendata/indonesia-earthquake-tsunami/. Accessed 30 Oct 2018

Hornbach MJ, Braudy N, Briggs RW, Cormier MH, Davis MB, Diebold JB, Dieudonne N, Douilly R, Frohlich C, Gulick SPS, Johnson III HE, Mann P, McHugh C, Ryan-Mishkin K, Prentice CS, Seeber L, Sorlien CC, Steckler MS, Symithe SJ, Taylor FW, Templeton J (2010) High tsunami frequency as a result of combined strike-slip faulting and coastal landslides. Nat Geosci 3:783-788
International Research Institute of Disaster Science (2018) 2018 Sulawesi earthquake and tsunami, Retrieved from http://irides.tohoku.ac.jp/topics_disaster/2018sulawesieq.html. Accessed 30 Oct 2018

Mafella R (2018) Batik Air ID 6231 scheduled to depart at 17.55, door closed at 17.52 then pushed back. 18.02 after cleared for take off, tower building collapsed. [Instagram Post], Retrieved from https://www.instagram.com/p/BoRttnsn5po/?taken-by=icoze_ricochet. Accessed 30 Oct 2018

Reuters (2018) Indonesia's quake-hit Sulawesi island from above, Retrieved from https:// www.reuters.com/news/picture/indonesias-quake-hit-sulawesi-island-froidUSRTS23SN1. Accessed 30 Oct 2018

Reuters Graphics (2018) Destruction in Palu, Regrieved from https:// fingfx.thomsonreuters.com/gfx/rngs/INDONESIA-QUAKE/010080MZ19R/index.html. Accessed 30 Oct 2018

Sassa S, Sekiguchi H (2010) LIQSEDFLOW: role of two-phase physics in subaqueous sediment gravity flows. Soils Found 50(4):495-504

Sassa S, Sekiguchi H (2012) Dynamics of submarine liquefied sediment flows: theory, experiments and analysis of field behavior. Adv Nat Tech Hazards Res 31:405-416

Sudibyo M (2018) Wave record from the tidal station of the Pantoloan port, Palu city at the time of tsunami event [twitter post], Retrieved from https://twitter.com/marufins/ status/1047467798996242433. Accessed 30 0ct 2018

USGS (2018) Earthquake hazards program, Retrieved from https://earthquake.usgs.gov/ earthquakes/search/. Accessed 30 0ct 2018

Valkaniotis S (2018) Displacement from \#Sentinel2 @CopernicusEU image frames for the whole length of the \#Palu \#earthquake sequence. [twitter post] Retrieved from https://twitter.com/SotisValkan/status/1047515941570007042. Accessed 30 Oct 2018

S. Sassa $(\nabla) \cdot$ T. Takagawa

Port and Airport Research Institute,

National Institute of Maritime, Port and Aviation Technology,

3-1-1 Nagase, Yokosuka, 239-0826, Japan

Email: sassa@pari.go.jp 